\title{
Water stability influence of host rocks on the process of water filtration into mine working with frame and roof-bolting support
}

\author{
Viktoriia Krukovska ${ }^{1, *}$, and Yurii Vynohradov ${ }^{2}$ \\ ${ }^{1}$ Institute of Geotechnical Mechanics named by N. Poljakov of National Academy of Sciences of \\ Ukraine, 49005, Dnipro, Simferopolska Str., 2a, Ukraine \\ ${ }^{2}$ Institute for Physics of mining processes NAS of Ukraine, 49005, Dnipro, Simferopolska Str., 2a, \\ Ukraine
}

\begin{abstract}
The water stability influence of host rocks on water filtration process from the undermined aquifer to the mine working, depending on the way of its fastening has been studied in the paper. When solving the problem of water filtration in a deformable massif, the finite element method was used. The results of calculations are presented of the filtration permeability of the coal-bearing massif, the water pressure and the value of the water inflow into mine working in the cases of mining operations in sandstone and argillite. It is shown that the use of roof-bolting support prevents the development of the fractures formation process in the mine working roof, preserving the rocks in a natural, monolithic state. As a result, the process of water filtration from water bearing rock layers is constrained, which prevents or significantly reduces the soaking of border roof rocks. The use of roof-bolting fastening several times reduces the water inflow into mine working, located even in water-permeable rocks. The application of the roof-bolting support as a technological method for reducing the water inflow into mine workings has been substantiated.
\end{abstract}

\section{Introduction}

The development of the mineral raw material base of Ukraine is connected with the necessity to develop the deep-seated deposits in conditions of increased water content of host rocks. This leads to rock falls and water breakthroughs, an increase in the cost for maintaining and repairing of mine workings. In the studied conditions, the problem of reducing the water inflow and ensuring the safety of mining operations is a priority.

Earlier, the authors noticed that the use of roof-bolting support helps to prevent the development of the fractures formation process in the zone of mine working influence. A significant reduction in the sizes of the filtration area and a decrease in permeability inside of it leads to a decrease in the filtration movement intensity and to prevention (reduce) the water inflow into mine workings fastened by roof-bolting support [1]. These studies have been performed for a specific lithological composition of the host rocks, whose properties are slightly changed when saturated with water. However, the strength properties of rocks

*Corresponding author: igtm@ukr.net 
may decrease when they are moistened, and as a result of their soaking, the process of border rocks destruction occurs more intensively [2-4]. The water stability of mine rock is a parameter characterizing the relative change in the strength of mine rocks when saturated with water [5]. The water stability is assessed by the soaking capacity factor, which is equal to the ratio of the compressive resistance of the rock, maximally saturated with water, to its breakdown point in the dry state. According to the value of the soaking capacity factor, the rocks are subdivided into water-stable; with lowered water stability; with weak water stability; water-permeable rocks [5].

In this regard, the objective of this work is to study the water stability influence of the host rocks on the process of water filtration into mine working at different ways of its fastening.

\section{Methods}

The water filtration from water bearing rocks into mine working, provided that the deformable massif permeability depends on its stress state, is described by the system of equations:

$$
\begin{gathered}
c_{g} \frac{\partial u_{i}}{\partial t}=\sigma_{i j, j}+X_{i}(t)+P_{i}(t) ; \\
k=f\left(\sigma_{i j}\right) \\
\frac{\partial p}{\partial t}=\frac{k}{\mu \cdot \beta \cdot m_{p}}\left(\frac{\partial^{2} p}{\partial x^{2}}+\frac{\partial^{2} p}{\partial y^{2}}\right)+q(t),
\end{gathered}
$$

where $u_{i}$ - the displacements, $\mathrm{m} ; c_{g}$ - the damping coefficient, $\mathrm{kg} /\left(\mathrm{m}^{3} \cdot \mathrm{s}\right) ; \sigma_{i j, j}-$ the derivatives of the stress tensor components along $x, y, \mathrm{~Pa} / \mathrm{m} ; X_{i}(t)$ - the projections of the external forces acting on the volume unit of a solid body, N/m $3 P_{i}(t)$ - the projections of forces due to fluid pressure in the porous fractured space, $\mathrm{N} / \mathrm{m}^{3} ; k$ - the permeability coefficients, D; $m_{p}$ - porosity; $f\left(\sigma_{i j}\right)$ - the function determined in $[1,5] ; p$ - the fluid pressure, $\mathrm{Pa} ; \mu$ - water viscosity, $\mathrm{Pa} \cdot \mathrm{s} ; \beta$ - water-compressibility factor, $1 / \mathrm{Pa} ; q(t)-$ the water release function.

The initial and boundary conditions:

$$
\begin{array}{rll}
\left.\sigma_{y y}\right|_{t=0}=\gamma H ; & \left.u_{x}\right|_{t=0}=0 ; & \left.u_{x}\right|_{\Omega_{1}}=0 ; \\
\left.\sigma_{x x}\right|_{t=0}=\lambda \gamma H ; & \left.u_{y}\right|_{t=0}=0 ; & \left.u_{y}\right|_{\Omega_{2}}=0 ; \\
\left.p\right|_{\Omega_{3}, t=0}=3.5 \mathrm{MPa} ; & \left.p\right|_{\Omega_{1} \text { and } \Omega_{2}}=p_{0} ; & \left.p\right|_{\Omega_{4}}=0.1 \mathrm{MPa},
\end{array}
$$

where $\gamma$ - the averaged weight of overlying mine rocks, $\mathrm{N} / \mathrm{m}^{3} ; H$ - the depth of mining, $\mathrm{m} ; \lambda$ - the side thrust coefficient; $\Omega_{1}$ - the vertical boundaries of the outer contour; $\Omega_{2}$ - the horizontal boundaries of the outer contour; $\Omega_{3}$ - the area of water-flooded rocks; $\Omega_{4}$ - the contour of mine working.

The problem is solved by the finite element method in an elastic-plastic formulation with the use of Mohr-Coulomb strength condition. At each time iteration, the influence of the stress field on the formation of the filtration area, the influence of change in water pressure on the stress state and the decrease in the strength properties of rocks during soaking are taken into account [6]. The roof-bolting support is modelled by rod finite elements [7], the frame support - by means of change in the finite element properties on the contour of mine working. 
Let us consider the preparatory mine working of an arch section $3.5 \mathrm{~m}$ in height, in the roof of which at a height of $0.5 \mathrm{~m}$ there is a water bearing coal interlayer with a thickness of $m=0.4 \mathrm{~m}$, and with a formational water pressure $3.5 \mathrm{MPa} ; p_{0}=1.2 \mathrm{MPa} ; \beta=1$.

Let us perform the calculation of filtration permeability and water pressure in the filtration area for four cases:

- mine working with frame support, being driven on sandstone which belongs to the rocks with lowered water stability;

- mine working with roof-bolting support, being driven on the same type of sandstone;

- mine working with frame support, being driven on argillite, which belongs to the water-permeable rocks with water stability by 2 times lower than that of sandstone; - mine working with roof-bolting support, being driven on argillite with the same properties.

The finite element grid with a water bearing coal interlayer is shown in Figure 1.

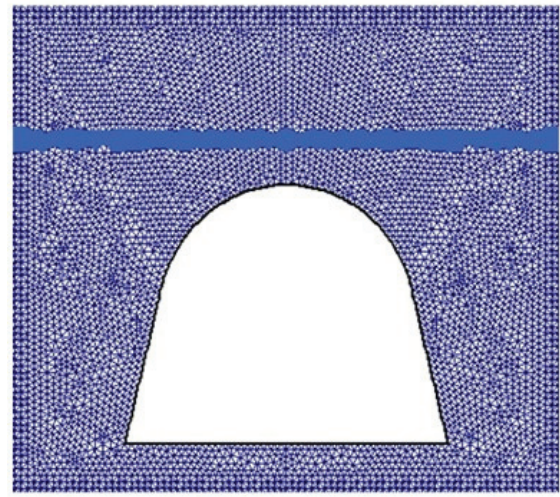

a)

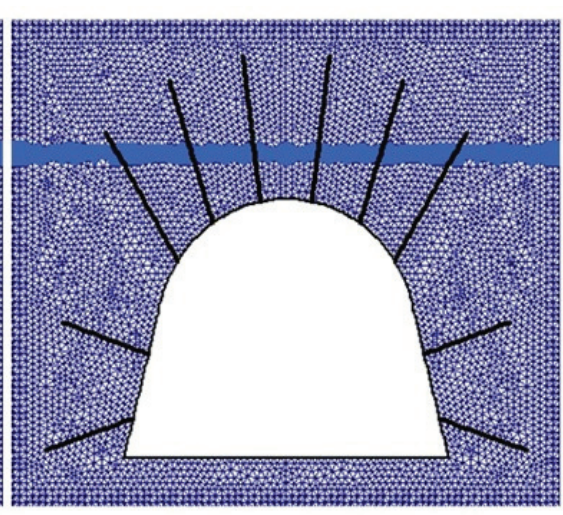

b)

Fig. 1. The central fragment of the finite element grid, the water bearing coal interlayer above the mine working: a) with frame support; b) with roof-bolting support.

\section{Results and discussion}

The distributions of permeability coefficients values of the rock massif around mine working have been obtained as a result of performed calculations in the specified cases. The results of calculation for the 30th time iteration (about 8 hours) are shown in all figures. It can be seen that at the current time around mine working with frame support, the filtration area with a depth to 1.5-2 $\mathrm{m}$ has been formed (Fig. 2), into which the water bearing coal interlayer enters. Inside this area, the water can move freely from the coal interlayer to the mine working contour. The permeability of water-permeable roof rocks (Fig. 2b), has higher values.

It can be seen from Figure 3, how the contours of the filtration area are changed, if the roof bolts are set in the roof and sides of mine working. The depth of the permeable zone in the roof is reduced by 2 times. The area of intersection of the water-flooded interlayer with the zone of increased permeability is very small even in water-permeable argillite (Fig. 3b). The roof-bolting fastening prevents the development of the fractures formation process in the mine working roof, preserving the rocks in a natural, monolithic state. As a result, the process of water filtration from water bearing rock layers is constrained, which prevents or significantly reduces the soaking of border roof rocks. 

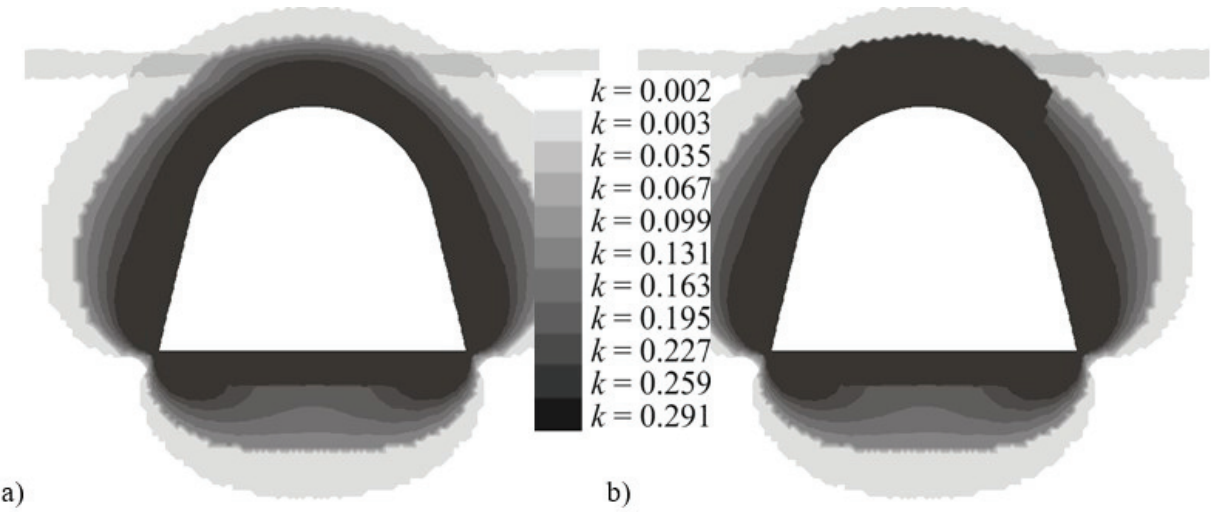

Fig. 2. The distributions of permeability coefficients values of the rock massif around mine working with frame support: a) host rocks - sandstone; b) host rocks - argillite.

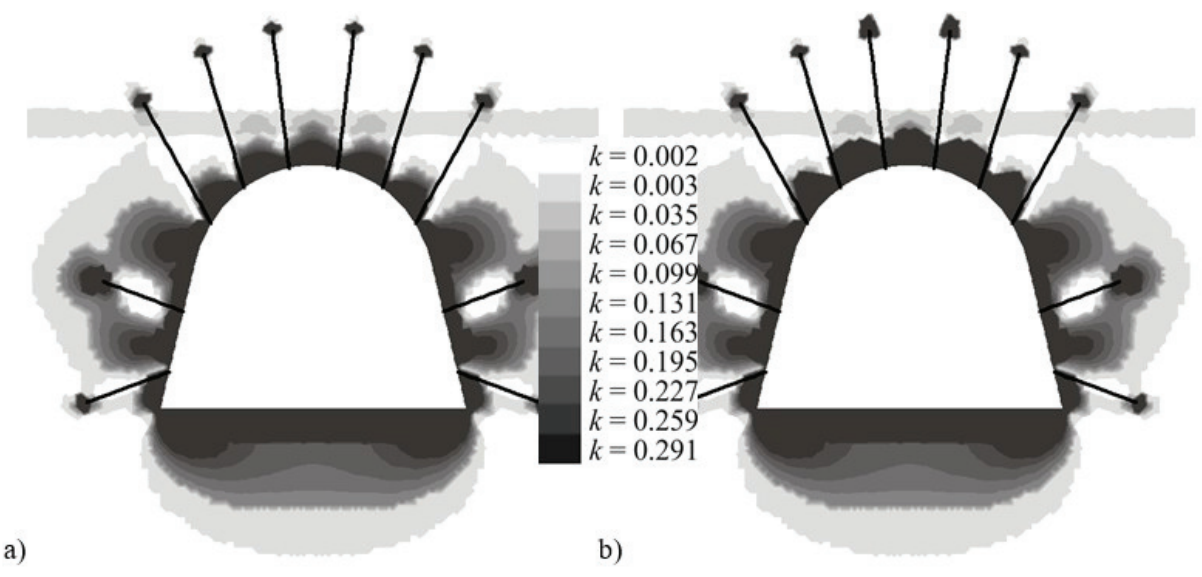

Fig. 3. The distributions of permeability coefficients values of the rock massif around mine working with roof-bolting support: a) host rocks - sandstone; b) host rocks - argillite.

The distributions of water pressure values are shown in Figures 4, 5. The process of water filtration occurs intensively in the roof of mine working with frame support. The water pressure in the undermined water-flooded interlayer decreases, (Fig. 4a, b), and the water moves from areas with higher pressure to where the pressure is minimal - into mine working. The area of low pressure in water-permeable rocks has a significantly larger sizes.

When the roof-bolting support is used, the water pressure in the undermined interlayer is practically unchanged even in water- permeable rocks (Fig. 5a, b), which indicates a very low intensity of the filtration process. This occurs as a result of a reduction in the filtration area and a significant decrease in the values of the permeability coefficients of border rocks. The length of the zone of water-flooded interlayer, from which water is filtered, is by 4 times shorter when fastening by the roof bolts.

The graph (Fig. 6) shows the calculated values of water inflows into mine working in the specified cases.

It can be seen that a decrease by 2 times in the soaking capacity factor of host rocks leads to an increase by $66 \%$ in water inflow into mine working with frame support, and into mine working with roof-bolting support - only by $20 \%$. The use of roof-bolting support reduces the water inflow into mine working, located in water-stable rocks, by 2.5 times, in water-permeable rocks - by 3.4 times. The method of roof-bolting support 
application in order to reduce water inflows into mine workings is confirmed by a patent [8].

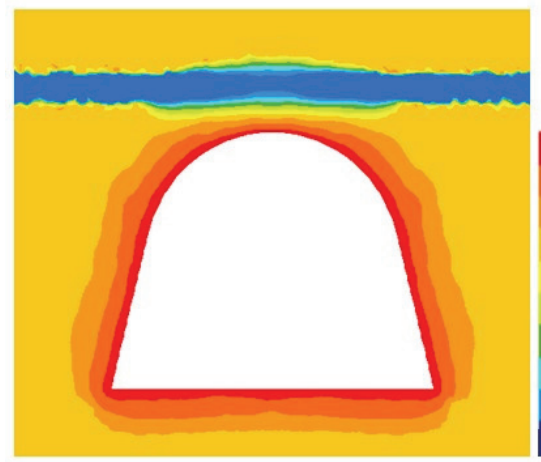

a)

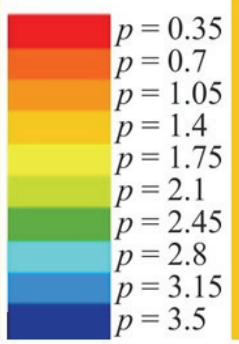

b)

Fig. 4. The distributions of water pressure values, MPa, in mine working with frame support: a) host rocks - sandstone; b) host rocks - argillite.

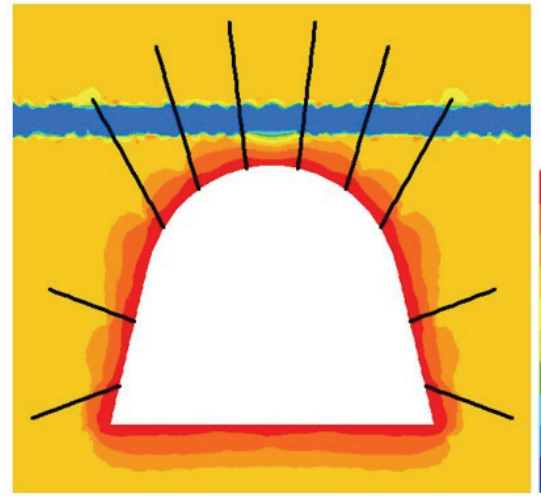

a)

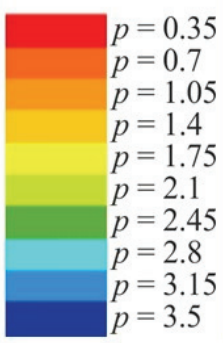

b)

Fig. 5. The distributions of water pressure values, $\mathrm{MPa}$, in mine working with roof-bolting support: a) host rocks - sandstone; b) host rocks - argillite.

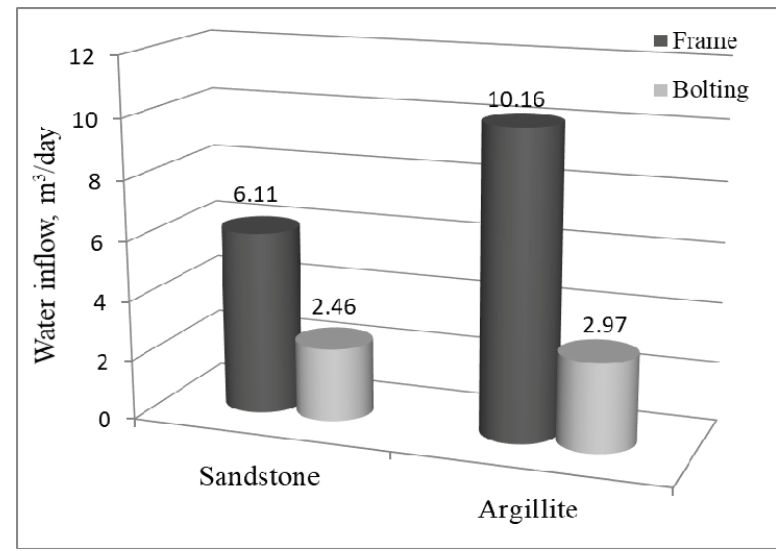

Fig. 6. Changing the values of water inflow into mine working with frame and roof-bolting fastening in rocks with different water stability. 


\section{Conclusions}

A numerical simulation has been performed of water filtration process in a deformable coal-bearing massif around mine working, depending on the method of its fastening and the soaking capacity factor of mine rock. The fields of filtration permeability of the massif, the water pressure and the values of water inflow into mine working for the specified cases have been calculated.

It is shown that the use of roof-bolting support prevents the development of the fractures formation process in the mine working roof, preserving the rocks in a natural, monolithic state. As a result, the process of water filtration from water bearing rock layers is constrained, which prevents or significantly reduces the soaking of border roof rocks. Therewith, the depth of the permeable zone in the roof, as well as the area of intersection of the water-flooded interlayer with the zone of increased permeability are reduced significantly even in the water-permeable rocks. A decrease by 2 times in the soaking capacity factor of host rocks leads to an increase by $66 \%$ in water inflow into mine working with frame support, and into mine working with roof-bolting support - only by $20 \%$. The use of roof-bolting support reduces the water inflow into mine working, located in water-stable rocks, by 2.5 times, in water-permeable rocks - by 3.4 times.

Thus, the roof-bolting support can be used as a technological method for reducing the water inflow into mine workings.

\section{References}

1. Krukovskyi, O., Krukovska, V., Vynohradov, Y. (2017). Mathematical modeling of unsteady water filtration in anchored mine workings. Mining of Mineral Deposits, 11 (2), 21-27

2. Vynohradov, V.V. (1989). Geomehanika upravleniya sostoyaniem massiva vblizi gornyih vyirabotok. Kyiv: Naukova dumka

3. Bezazyan, A.V., Sadovenko, I.A., Dudlya, N.A. (1983). Interaction between waterbearing rocks and excavation workings. Metallurhycheskaia y hornorudnaia promyshlennost, 4, 35-36

4. Pitalenko, E.I., Vasyutina, V.V., Revva, V.N. (2011). The effect of moistening of rock on the activation of geomechanical processes under closing coal mines. Transactions of UkrNDMI NAN Ukraine, 8, 117-127

5. Gornaya entsiklopediya. (1991). Moskva: Sovetskaya entsiklopediya

6. Krukovska, V.V., Krukovskyi, O.P., Vynohradov, Y.O. (2017). Sposib doslidzhennia stanu obvodnenoho hirskoho masyvu navkolo hirnychoi vyrobky. Patent No 114572, Ukraine

7. Krukovskyi, O.P (2005). On the issue of anchoring simulation. Geotehnicheskaya mehanika, 57, 54-59

8. Krukovska, V.V., Krukovskyi, O.P., Vynohradov, Y.O. (2016). Sposib znyzhennia vodopryplyvu u hirnychu vyrobku iz zastosuvanniam ankernoho kriplennia. Patent No 111059, Ukraine 